Jelena Anđelković

UDK 904:726.8"652/653"(497.11)

Archaeological Institute, Belgrade

$75.032 / .033 .042$

jelenandjelkovic@gmail.com

Original research article

Dragana Rogić

Archaeological Institute, Belgrade

Received: April 08, 2010

Accepted: August 02, 2010

Emilija Nikolić

Archaeological Institute, Belgrade

\title{
PEACOCK AS A SIGN IN THE LATE ANTIQUE AND EARLY CHRISTIAN ART
}

\begin{abstract}
In the art of late antiquity and early Christianity, during the Christian Middle Ages to the present, peacock holds a prominent place, not only as a decorative motif, but also as a distinctive emblematic and symbolic sign. Veneration and breeding of this bird is dating back to distant past. Owing to the beauty of his plumage and splendid tail, peacock has early got a lot of symbolic functions, causing he to become a very frequent artistic motif. Because of his protective functions, he is a characteristic sign in funerary art. On this example, the transposition of the same motif from pagan to Christian iconography is most noticeable. He is usually combined with a kantharos or a tree of life. These scenes are common in the late antique and early Christian fresco painted tombs from the territory of modern Serbia. Individually or in pair, he is usually represented on places which are the ones closest to the holiest part of churches (altar's parapet wall panels). His ornamentation is visible on floor mosaics, which are often a sole testimony of the decoration of public buildings from the early Christian period, and whose remains can be found on the territory of the Roman provinces on the Central Balkans.
\end{abstract}

Key wORds: PeAcock, Sign, ART, Painting, late AntiQuity, EARly Christianity, tombs, FRESCOES, MOSAIC.

\section{THE ORIGIN AND MEANING OF PEACOCK}

Peacock (Greek $\pi \alpha \gamma \omega ́ v ı, \tau \alpha \omega ́ \varsigma$, Latin $p a-$ vus or pavo) belongs to the gender of hens. Due to his exceptional natural characteristics, he very early received an honorable place among birds. ${ }^{1}$

1 Peacocks differ from other hens with upper tail's plum-
The so-called ordinary peacock (pavo cristatus) is the most depicted one. (Fig. 1.) Iconographically

age, which is especially big and oversized. Therefore, this plumage can be considered as the most important feature of peacocks. They have solid structure and long necks, small heads, short wings, high legs and long tails. Peacock's body is covered with luxury plumage, and his head is decorated with an upright and a long, narrow feather with a brush-hook at the top. Peacocks reach the peak of his beauty at the age of three. (Brem 1982: 309-310)

* The article results from the project: Viminacium, Roman city and military legion camp - research of material and non material of inhabitants by using the modern technologies of remote detection, geophysics, GIS, digitalisation and 3D visualisation (no 47018), funded by Ministry of Education and Science of the Republic of Serbia. 


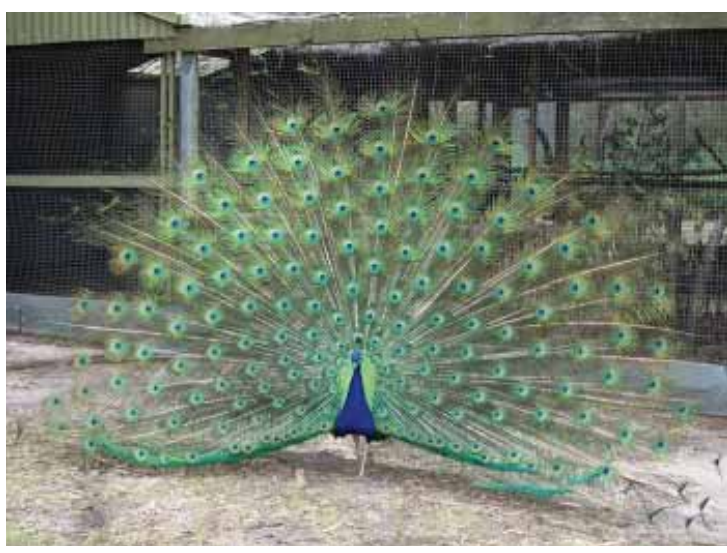

Fig. 1. Peacock (Pavo cristatus).

and stylistically, his natural look was mimed in art. If we compare his description with the most of preserved representations, it is noticeable that the specific forms and colors of plumage are reproduced with precise sensibility. Head, neck and front chest of the peacock, are of scarlet blue color, with gold and green reflexes, while the back is green. Every single feather is decorated with copper colored edges. Green tail plumage is decorated with eye-shaped flecks. (Brem 1982: 309310). (Fig. 2.) It is this distinctive feature of the tail gives basis for symbolical meaning which was referred to the peacock in ancient time and during Middle Ages.

Peacock originates from Ceylon and India, where he was regarded as a symbol of the sun, because of the luxuriant plumy "train" on the tail. Via Babylon, Persia and Asia Minor, he reached the island of Samos, and there he became a sacred bird in Hera's temple. (Biederman 2004: 291292). It is supposed that he was brought to Italy by Carthaginians. In Rome he was bred from the sec-
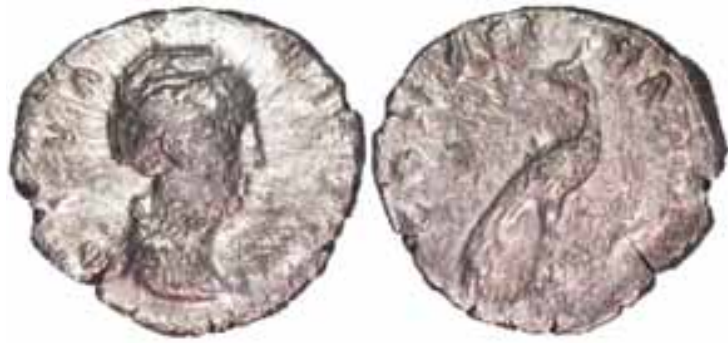

Fig. 3. Faustina the Elder on the obverse and peacock on the reverse side of coin.

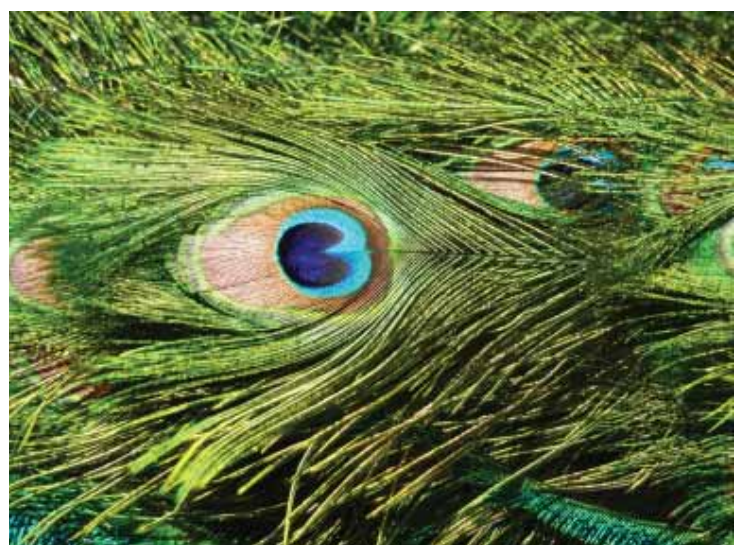

Fig. 2. "Eyes" on peacock's tail.

ond century BC and there he incorporated Juno's sacred animal. His depictions in Roman art are usually associated with this goddess. Juno was an enthroned ruler of the sky, her reflection on earth was incorporated in the image of an empress, so it is logical that her attribute - peacock is frequent on the reverse sides of coins of some Roman empresses between $1^{\text {st }}$ and $3^{\text {rd }}$ century AD. (Fig. 3.)

Herein, he is usually rendered in frontal position with an open tail or in profile with downcast tail. ${ }^{2}$ Because of his characteristic points, "eyes" on the tail, with time peacock has obtained multiple symbolic functions, so he becomes an almost inevitable motif in the visual and symbolic complex scenic repertoire of fresco painted tombs. In ancient times, he reached our region from the Mediterranean area. Artists who painted tombs, besides existent templates which they used as pattern, it is certain that they could have observed living birds of this gender. Visual arrangements of peacocks, in fresco painted tombs at the territory of present-day Serbia and in the neighboring countries are clearly rendered to imitate a real bird, with more or less success.

2 On the obverses are Domitia, wife of Domitian (the end of the $1^{\text {st }}$ century), Faustina the Elder, wife of Antoninus Pius (middle of the $2^{\text {nd }}$ century), Faustina the Younger, wife of Marcus Aurelius (second half of the $2^{\text {nd }}$ century) and Diva Mariniana, wife of Valerian I (middle of the $3^{\text {rd }}$ century). (RIC II, 179-180, Pl. XII, 212; RIC III, 66-77, 157-170, 190-194, Pl. III, 64; RIC V/1, 64-65, Pl. I, 11, $12,13)$. 


\section{PEACOCK AS A PICTORIAL SIGN}

As a motive in funerary painting, he is usually placed within scenes which evoke Elysium or Garden of Eden, paradise. These representations of gardens really can be located behind some paradisiacal enclosure, but sometimes arrangement of motifs and adequate scenes, by itself allude to the Garden of Eden, although it is not always formally depicted as such. Besides plenitude of vegetable motifs, different species of birds inhabit these places of bliss; among them, the most common are the representations of pigeons and peacocks. ${ }^{3}$ Because of the similarity in decoration and the same symbolic function often combined within a single composition, pigeons in vineyards and peacocks with grapes can be found.

Both representations were conventional in the Greco-Roman funerary iconography because of their allusions to paradise. In the Balkan's tombs from the third to the sixth century a whole range of different forms of these motives could be seen. Unlike birds which may and need not to be recognized by natural features, ${ }^{4}$ peacocks are so typical, that in the Garden of Eden, they are not in the function of decorative completion of the idyllic scene, they already independently act symbolically, in accordance with the surrounding scenery. They are one of the most beautiful and most popular themes in sepulchral art in Antiquity, because of the fact that through vines and grapes they are associated with the god Dionysus, and also they

3 From all vegetable motifs low shrubs (which are not often defined botanically) and vines with birds (generally recognized as pigeons) are usually shown. In such combination, they are an allusion to the paradise gardens and are usual iconographic repertoire of the late antique and early Christian funerary painting on the territory of Serbia. (Rakосіja 2009: 87-105; Мирковић 1954-1955: 53-71)

4 About the fact that for painters of a certain epoch, it was important to show the bird as such (probably schematically long enough exploited to recognizable) in the characteristic expressive manner, testified two pairs of birds from the "Tomb with Cupids" marked as G160. (Korać 2007: 125-140, fig. on the page 135). About expressionist artistic expression in late antiquity, $c f$. (Čremošnik 1984: 198-199). are attributes of a supreme female deity of the Romans - Juno. (Cermanović and Srejović 1996: 107-110, 212-213, 263-265) A special meaning is assigned to the peacock tail, with its "eyes" which symbolize stars in the sky, and often signify the idea of eternity. Wine, together with peacocks can be understood as the potion of immortality, the symbol of Dionysus' liturgy. Confronted peacocks, alone or with a kantharos, were directly transferred from the Dionysian into the Christian symbolism, bearing here their implications entirely. (Đurić 1985a: 5-18) Frequency of this scene in the Balkan's late antique and early Christian fresco painted tombs, on the early Byzantine mosaics, and its appearance throughout the whole Christian Middle Ages, made this theme popular today.

In funerary painting on the territory of Serbia we find peacocks in six tombs of Viminacium ${ }^{5}$ (Korać 2007: 18-25, 43-48, 69-72) and in one in Beška. (Đorđević 2007: 70-71; Маријански Манојловић 1987: 17 - 32; Đurić 1985: 5-18)

\section{PAGAN CONTEXT}

Viminacium - in the tomb marked as G-5464, (Korać 2007: 18-22) in the western part, two confronted peacocks are painted, among them there is a spherical amphora. The amphora is painted in linear manner, with dark brown color. Peacocks are rendered with contours of dark brown, which are filled with cobalt and light blue color. The other walls of the tomb are decorated with a combination of geometric and floral motifs. (Fig. 4.)

On each of the lateral walls of the tomb marked as G-4734, (Korać 2007: 22-23) in the surrounding of floral motifs, peacocks were painted. The peacock depicted on the western side still has most of the tail, wings and body with feet pre-

5 Because of the impossibility of precise dating (and thus defining the religious framework), tombs which have been fragmentary preserved are classified as pagan. 
served.

On the west side of the tomb G-3130 (Korać 2007: 23) beside geometrical motifs which imitate marble surface, on the south side, only a detail of feet of the former figure of a peacock has been preserved. (Fig. 5.)

Tomb G-5313 (Korać 2007: 23-25) is largely destroyed with looting. Two birds and vegetative motifs are preserved on the west and south, while on the eastern frontal side, inside a trapezoidal frame, a painted bird is probably the peacock. (Fig. 6, 6a.)

In the "Pagan tomb" marked as G-26246 on the northern and southern lateral walls, peacocks are depicted in the profile facing west, where there is the portrait of a deceased woman, to whom the whole tomb and paintings inside are consecrated. (Fig. 7, 7a.) With his multi-layered symbolism indicating the cults of Dionysus and

6 Based on stylistic and iconographic analysis, as well as by the coins found in the tomb, the tomb has been dated to the time of Constantius II, between 346 and 350. (Korać 1993: 107-122; idem. 2007: 69-100).
Juno, (Срејовић and Цермановић-Кузмановић 1979: 182-183) they are also the emblem of an empress or a princess, and with the meaning of the starry sky, they are related to the apotheosis and immortality. (Lother 1929: 283). They can be represented independently as here (in G2624) but more often in pair, when there is a kantharos between them. Although viewed individually, they independently occupy the whole panel in which they are represented, however, in a three-dimensional context, i.e. in the "scenery" of the whole architectural complex they are in pair, painted on the walls which are opposed. In this tomb, kantharos is located in front of both of the two peacocks, and it is filled with wine, which is represented with a dark, brown color. The symbolism of the kantharos filled with wine refers to the idea of immortality. Each motif of these painted panels should have possessed the function of deceased's victory over death. Thus, above the peacocks there are garlands, which in logical compositional and symbolic system should associate this idea with the deceased herself, and with garlands on

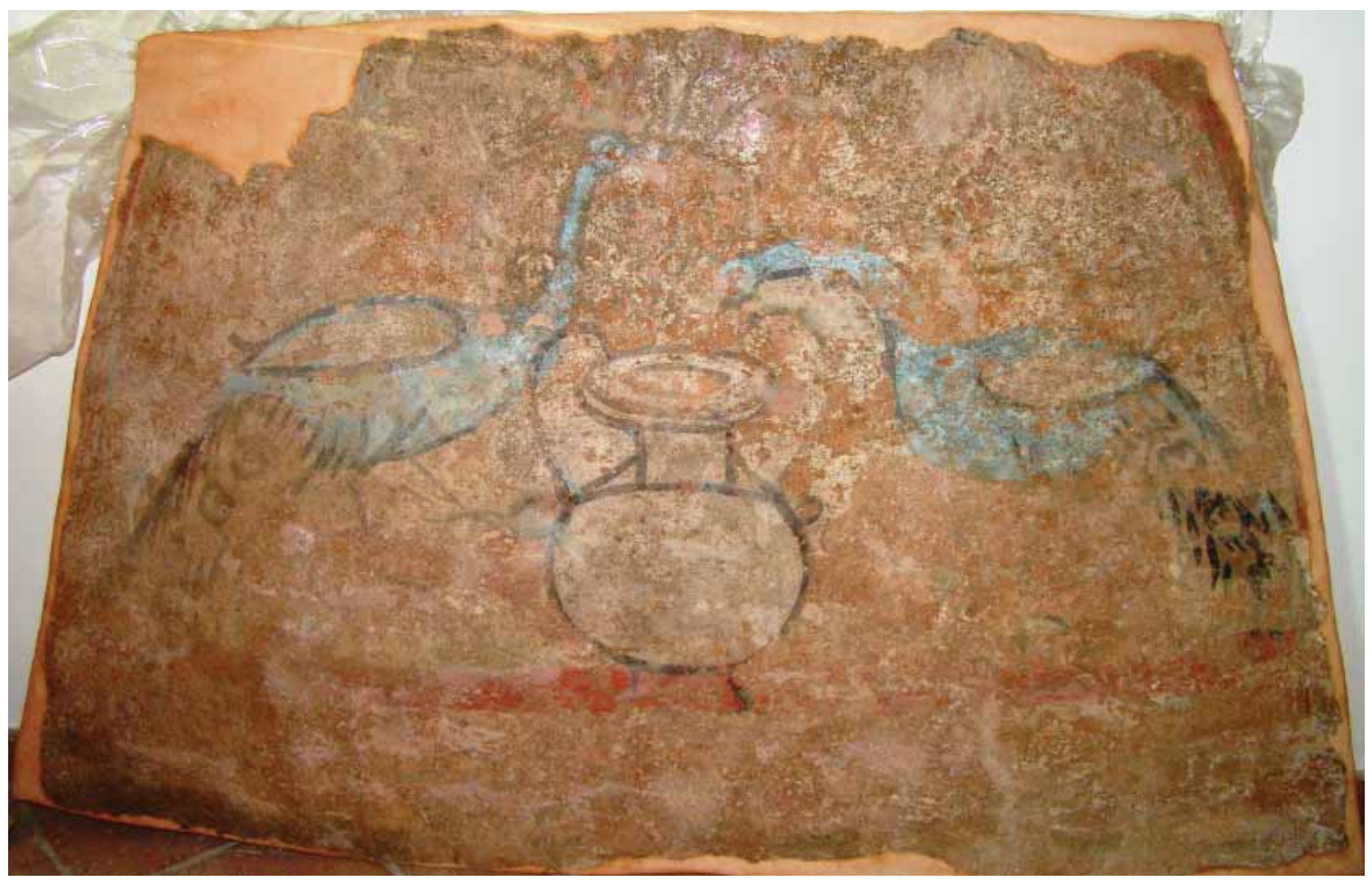

Fig. 4. Viminacium, two peacocks and amphora in the tomb G-5464. 
her panel. Above the peacock on the north side one garland is painted, and on the southern two. ${ }^{7}$

In terms of style in the compositional concept of the tomb elements of symmetry prevail, to which individual scenes are also subordinated. Peacocks on the lateral walls stand in balance with each other, as well as depictions of the deceased and the servant on the frontal walls. Both figures of peacocks are disproportionate with the figures of the deceased and the servant. Although it is known that an older male peacock actually can grow up to more than $2 \mathrm{~m}$, (Brem 1982: 309$310)$ the question is whether the artist really want-

7 Garlands are frequent motives on the sarcophagi, the so-called sarcophagi with garlands. There are relieves and tombstones with them, and sometimes they were used as a decorative element in architecture. As decorative elements on paintings, tradition of their representation dates back to the Hellenistic period. Christians also accepted them because of their meaning of triumph over death. Garlands incorporate dedication, honor, and they often play the role of assignment. In Roman funerary custom, they indicate life after death. The motif of garlands is also very common, there are to be found in almost every tomb of Illyricum. (Маријански - Манојловић 1987: 3) ed to keep the natural dimensions of the animal on the image (as this is not the case with human figures), or this oversized image automatically should actually represent an oversized symbolism of peacock. It is unusual in funerary painting that a single motive takes over the entire wall, unless it is not a representation of the deceased. By observing this representation in a special religious context, Goran Janićijević (Janićijević 2009: 135-143) noticed in his paper that here depiction in pair is important, which aims to increase the basic meaning of the central representation. ${ }^{8}$ So peacocks with a kantharos between them, facing a young woman, indicate that the deceased does not appear as a consumer of the image (icon of paradise) but that she herself is the icon of eternal life. ${ }^{9}$ Therefore, the basic iconographic and stylis-

8 It is known that multiplication of deities increase powers and activities of a certain deity, so as to respect the trinity, so therefore the visual depiction would have had three persons. This is an example of the three Graces, three Fates and three Matres. (Марић 2003: 42-45).

9 Although the tombs are known as Pagan in literature, by observing the peacocks in it, Janićijević considered the

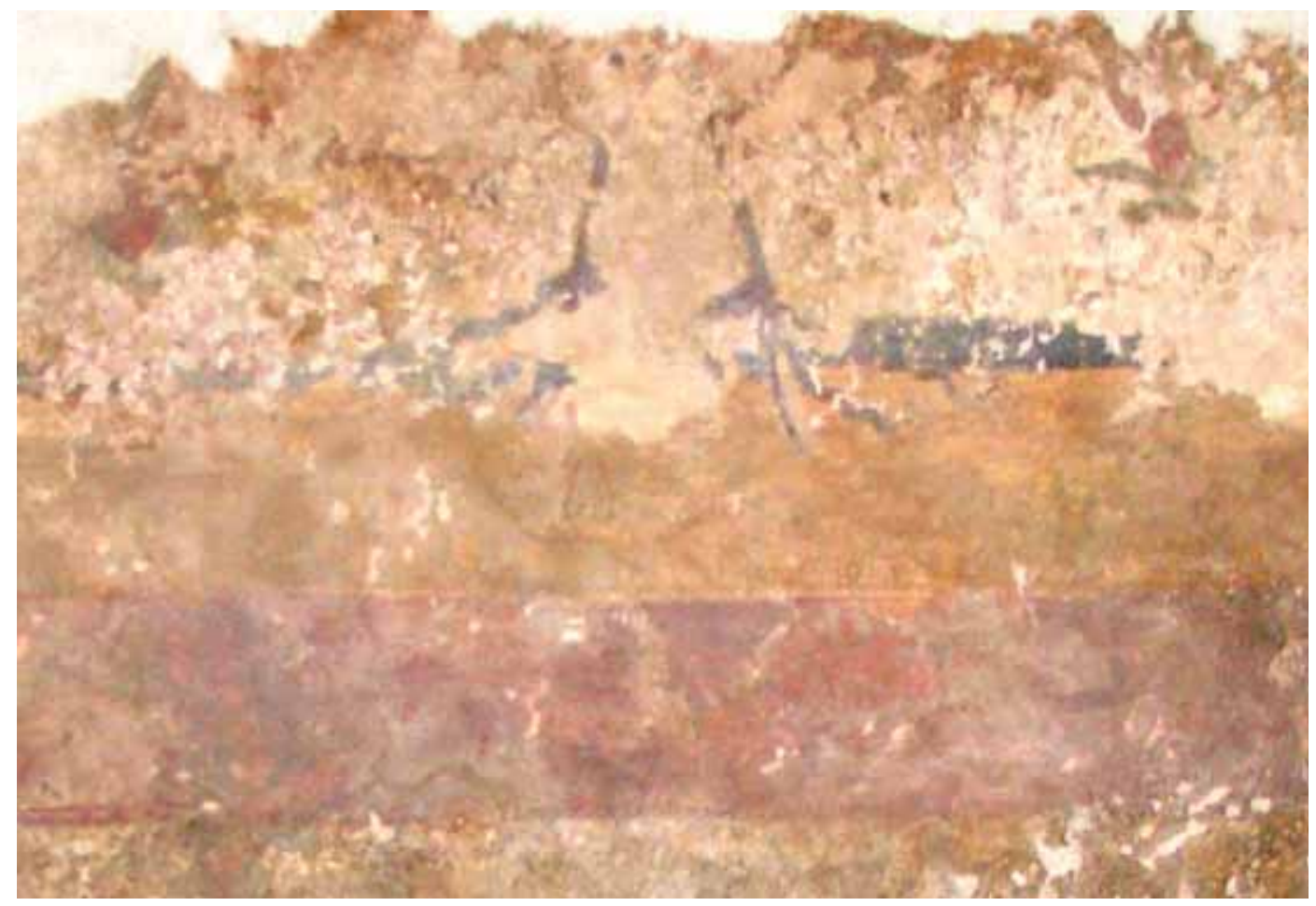

Fig. 5. Viminacium, detail of feet of the former figure of peacock in the tomb G-3130. 
tic idea of this tomb is the symbolic orientation of all composition's elements towards the portrait of the deceased. Hence oversized peacocks facing her reinforce the idea of her immortality.

Unlike precisely rendered figures and portraits of the deceased and the servant, the peacocks' bodies are rendered in a much more liberal manner, almost in impressionistic way of painting, with long and easy brush strokes. The drawing dominates, because it primarily builds the form, and it is filled with element of color. In all representation fine contour is visible, which describes the shape.

possibility of both religious frameworks. In both cases he perceives peacocks in the function of lasting, eternity and Elisium as eternal existence, i.e. as an antithesis to ephemeral (and as Resurrection reached through Christianity). (Korać 2007: 69-100; Јанићијевић 2009: 135-143).

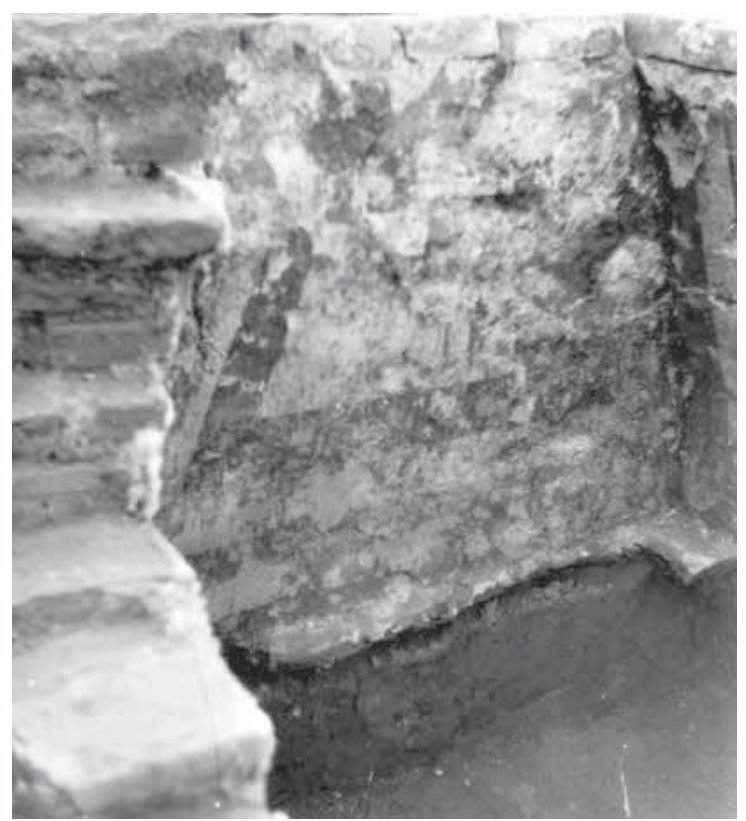

Fig. 6. Viminacium, detail of peacock in the tomb G-5313.

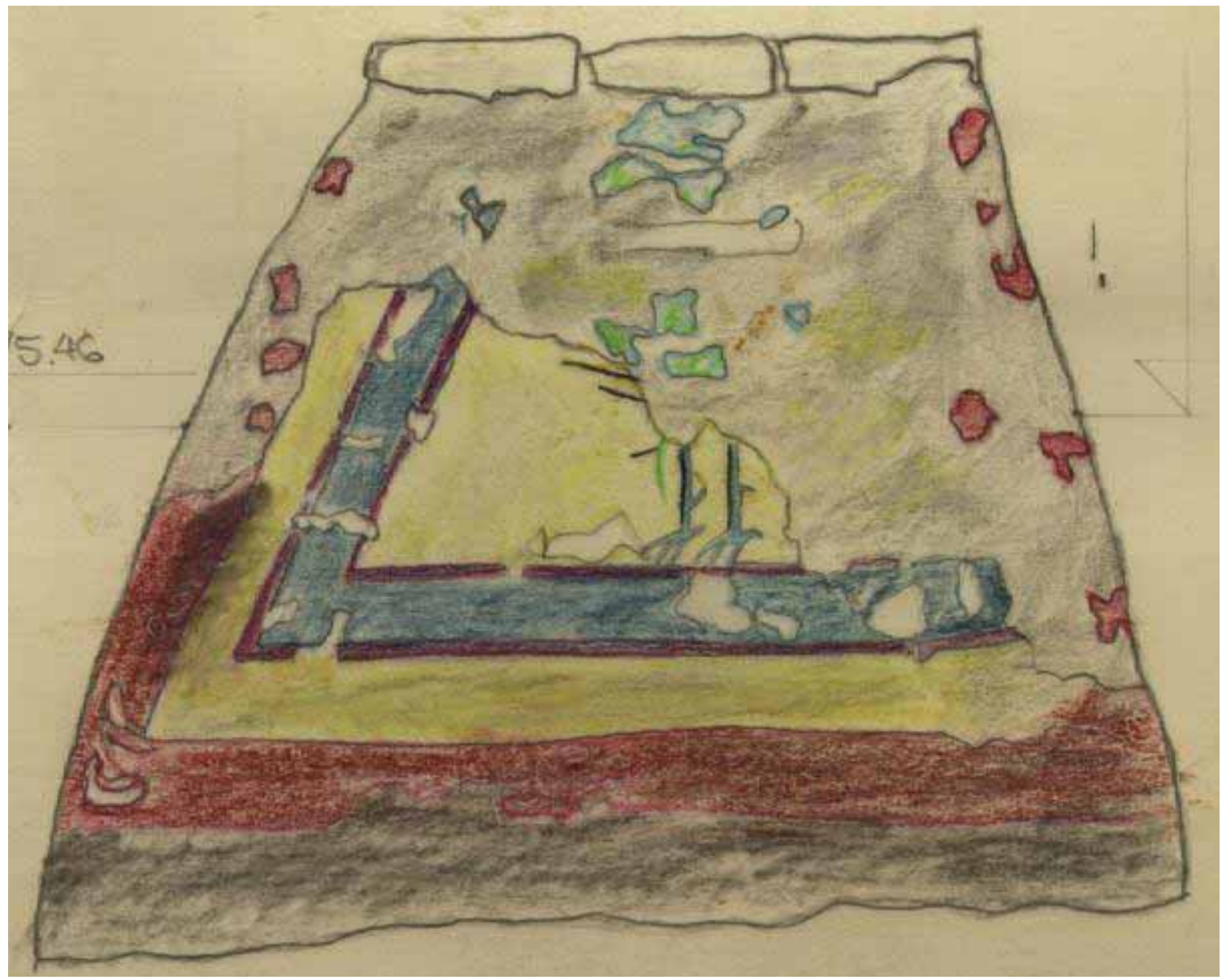

Fig. 6a. Viminacium, detal of peacock in the tomb G-5313, drawing by Srđan Đurić. 


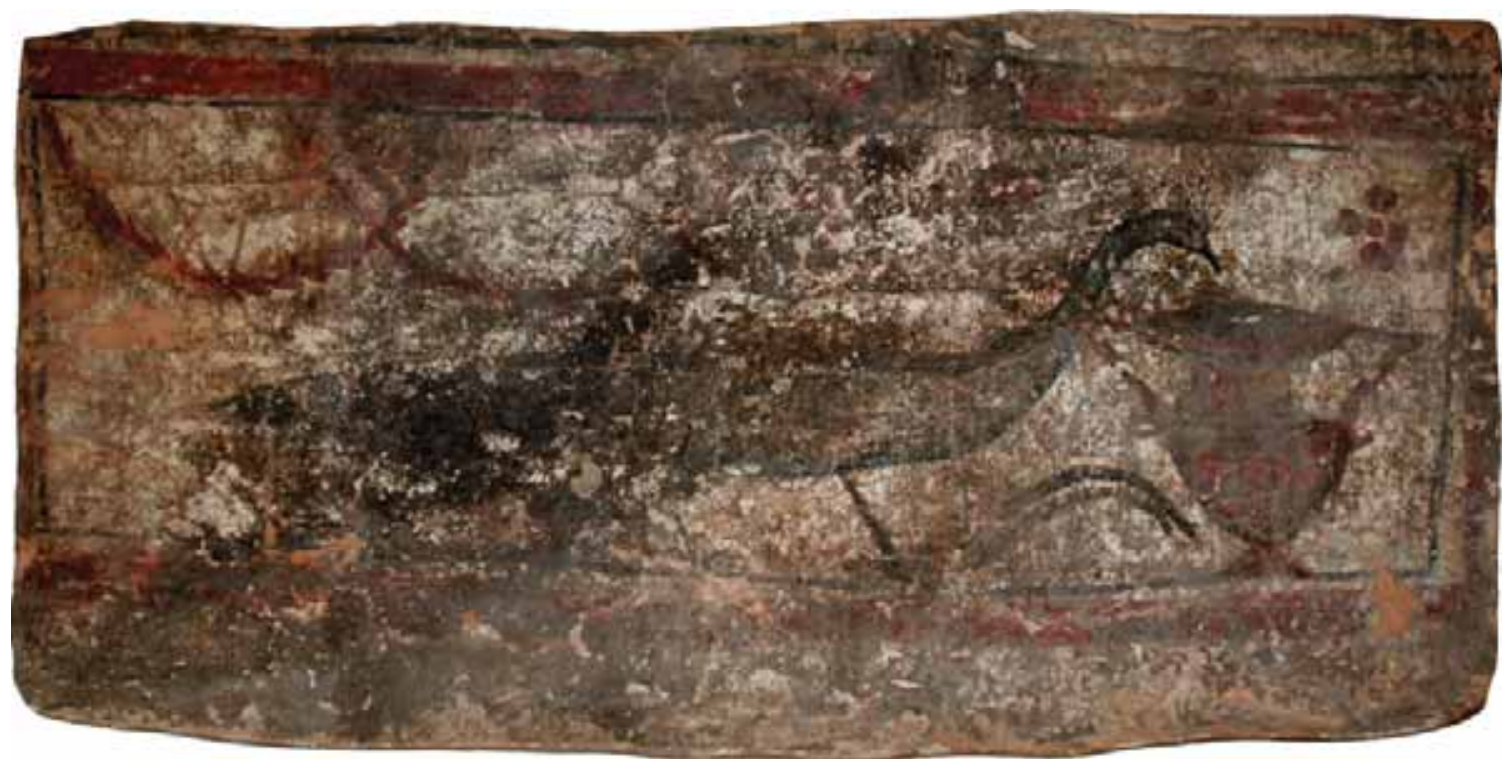

Fig. 7. Viminacium, peacock on the southern side of the "Pagan tomb" G-2624.

In the so-called "Tomb with Cupids" marked as G-160 (Korać 2007: 125-140), ${ }^{10}$ the western wall is damaged. Apart from the Cupid and figures of servants, all other motifs are zoomorphic and floral. Panels filled with grape vines, plants, birds (doves) and peacocks, should suggest

10 On the basis of an eclectic manner of art prior to Constantine and of Constantine's time, paintings from the "Tomb with Cupids" could be dated to the beginning of the fourth century. the afterlife. In such context peacocks are again an allusion to paradise and bliss of the second life. In particularly framed panels on longitudinal north and south sides, in spaces next to the eastern, frontal wall, there are peacocks depicted, symmetrically, but as in a mirror, one on each side. They are facing the main scene, i.e. the image on the west. ${ }^{11}$

11 Western wall in the fresco painted tombs in the most cases is intended for the portraits of the deceased (an

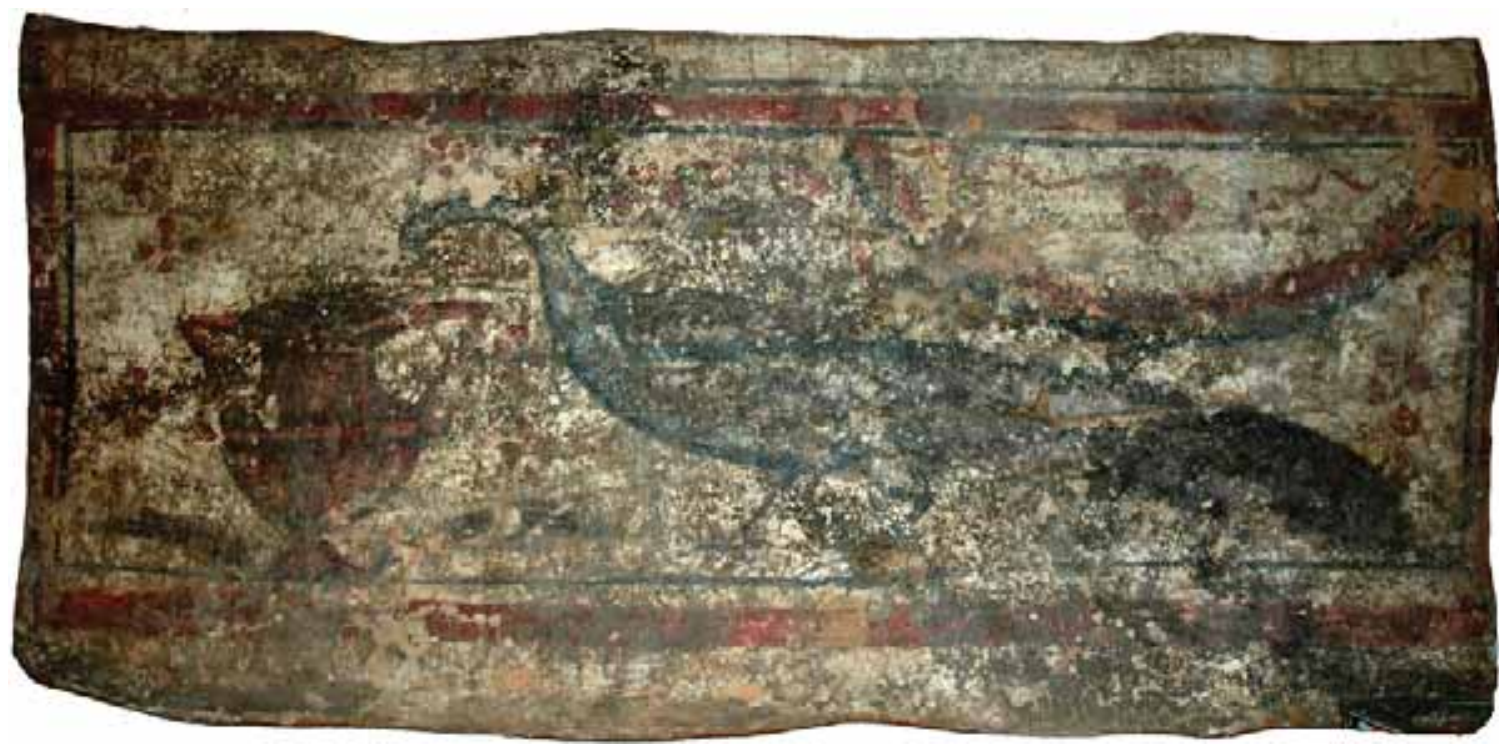

Fig. 7a. Viminacium, peacock on the northern side of the "Pagan tomb" G-2624. 
In front of them is a cone-shaped bowl or basket, filled with vivid colors which suggest flowers and fruits. Behind peacock's tail, in the distance, there is another similar basket. ${ }^{12}$

The remaining space of white background is filled with vegetable motifs, freely arranged plants, with large flowers on top. (Fig. 8, 8a) Because of the painted Cupids and vines, content of the tomb could be determined with Dionysian character. Certainly the usual interpretation of immortality and apotheosis can not be excluded, (Gerbran and Ševalije 2004: 679) and as always recognizable paradise and world of bliss, and typical in sepulchral art. Basket or bowl filled with fruit or herbs in front of the peacock also symbolizes fertility-yield, i.e., cornucopia, one that contains a drink of immortality. (Gerbran and Ševalije 2004: 345-347, 398, 689).

On the northern, lateral side of the tomb in Beška, (Đorđević 2007: 70-71; Маријански Манојловић 1987: 17-32; Đurić 1985a: 5-18) ${ }^{13}$ in the upper zone on a white background, three peacocks are depicted, two placed one opposite to another and the third one without pair. (Fig. 9) Peacocks' bodies are blue colored, wings are yellow with a black contour. Long tail is red with yellow and black accents and dotted blue ornament. Clusters and leaves fill the space between the peacocks. Common interpretations of vines, birds-peacocks who peck it, running spirals are peace and welfare of the deceased awaiting him

individual or a married couple), so to this wall i.e. embodiment of physical presence of the deceased in the tomb, all other depicted motives and scenes are subordinated. (Валтровић 1906: 128-138; Стричевић 1956 1957: 411-413; Овчаров and Ваклинова 1978: 26 - 27; Димитров and Чичикова 1986: 33-35; Danov and Ivanov 1980: 105-121; Marijanski-Manojlović 1987: 17-32; Korać 2007: 101, 129).

12 Since these utensils are placed in the context of the paradisiacal space, which is here granted with the presence of peacocks, we compare with a similar utensil with conical shape among scattered motives of paradise on the arch of ambulatory of the Church Sta. Costanza. (Oakeshott 1977: 57).

13 According to grave goods and coins, the tomb has been dated in early fourth century.

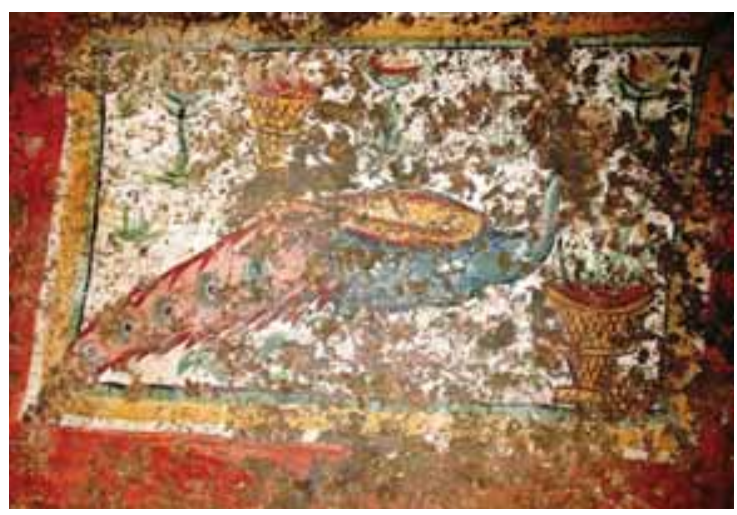

Fig. 8. Viminacium, peacock on the southern wall of the "Tomb with Cupids" G-160.

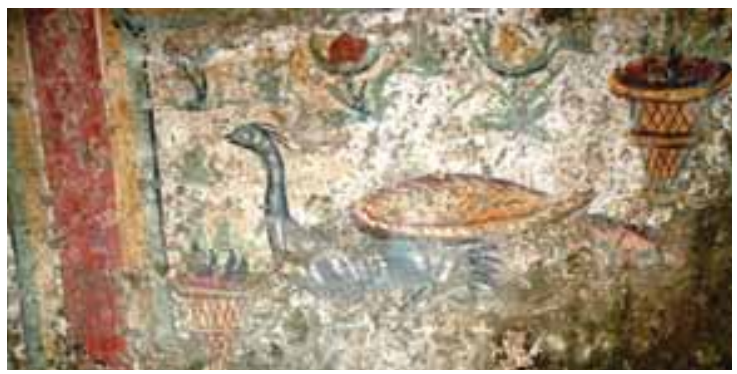

Fig. 8a. Viminacium, peacock on the northern wall of the "Tomb with Cupids" G-160.

after death. Imprecise division of the metope conditioned by architectural concept gives an impression that the artist started painting on the left. This created a bad conception of an image, including figures of peacocks, which are given in the form of frieze, so that the third, facing the opposite direction, lost his pair. Either as part of the heavenly landscape, or with kantharos in the Dionysian meaning, in the pagan character of the tomb, the peacock is a sign of victory over death, apotheosis and immortality. ${ }^{14}$

\section{CHRISTIAN CONTEXT}

There was no ultimate break with the pagan past in early Christian art, but many themes and motifs have been transposed from its initial pagan into a Christian context. Philosophy of death and

14 About the peacock in the fresco painted tombs of Illyricum in: (Đurić 1985b: 221-224). 


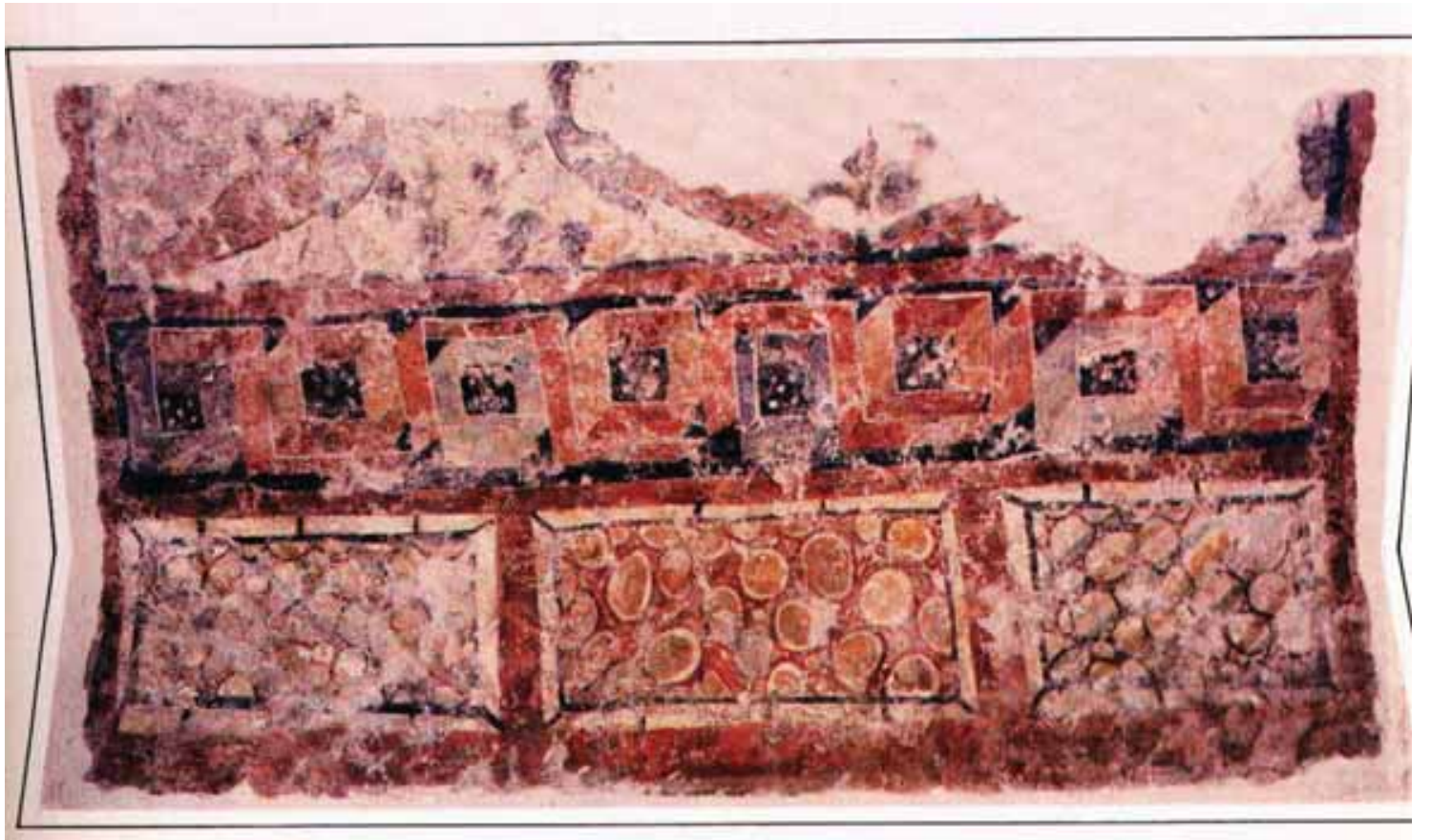

Fig. 9. Beška, three peacocks in upper zone of the northern side of the Beška tomb.

belief in the afterlife remained dominant ideas of Christian art, so artistic themes have been adjusted to this aspect of death. Besides Pastor Bonus and Oranta as the most frequent central motifs, scenes of grape harvest, vines and peacocks were more than an eagerly accepted heritage from the

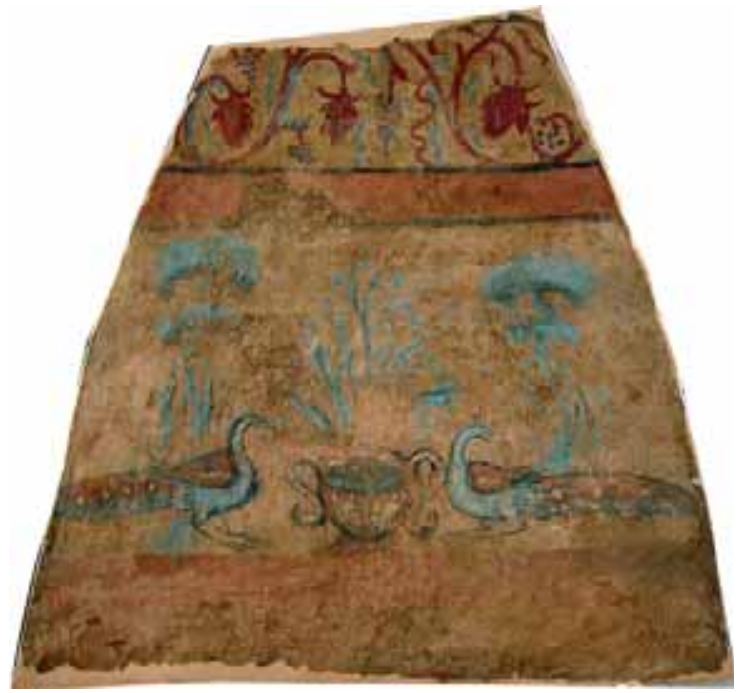

Fig. 10. Viminacium, Christian paradise with peacocks and kantharos on eastern wall of the

"Tomb with Christ's monogram" G-5517. pagan past. (Volbach 1961: 12).

In the "Tomb with Christ's monogram" G-5517 (Korać 2007: 33-62) ${ }^{15}$ as a match with the western scene with the monogram, on the east wall the Christian paradise is represented. There are painted peacocks over the kantharos, as a spring of life. Kantharos is here represented as a fountain from which holy water emerges, and behind each of the peacocks there is a tree of life. (Fig. 10) The peacock is, as we have seen, in many examples a specific symbol of immortality for pagans as well as for Christians. (Спасић-Ђурић 2002: 187-190) Kantharos between them is filled with blue color, therefore water. This is an already standardized image of peacocks who drink from "the spring of life", where they became symbols of human soul. (Јовановић 2009: 526). In combination with the tree of life, they are symbols of man's psychic dualism. (Gerbran and Ševalije 2004: 679-680). Tree of Life symbolizes the connection between

15 Coins of Constantine I from the year 307 were found in the tomb, but based on analogies, and above all stylistic elements, the tomb has been dated to the end of the second and the beginning of the third decade of the fourth century. 


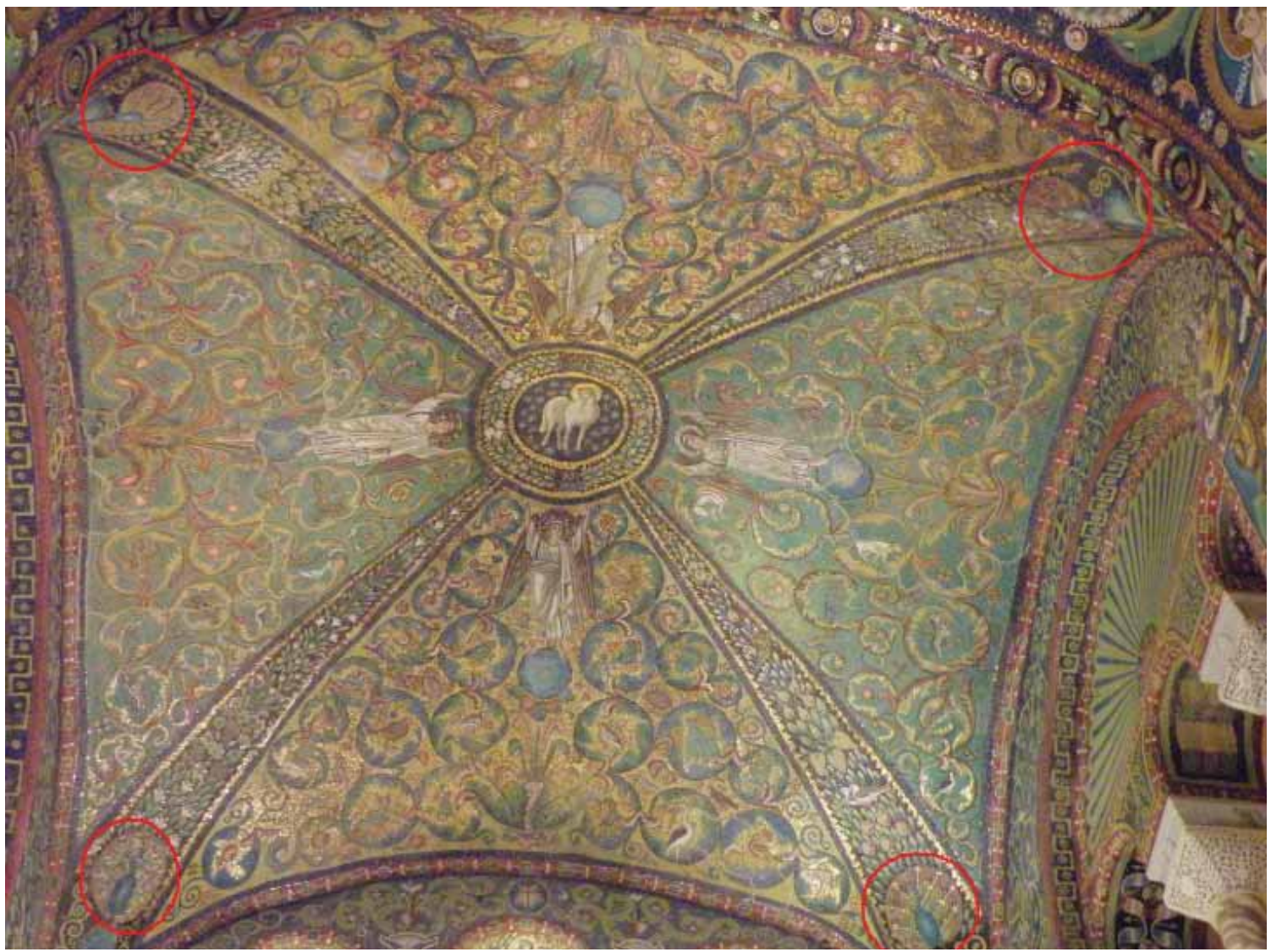

Fig. 11 - Church of San Vitale in Ravenna, peacocks on the ceiling of the presbytery.

heaven and earth, death and resurrection, and sometimes suggests crucifixion. Together, water and the tree of life, according to the Biblical interpretation, are ensuring eternal life and bliss to the deceased (Revelation 22, 14). ${ }^{16}$

Thus, besides that he decorates and belongs to established arrangement of paradisiacal garden, in ecclesiastical books it is considered that in the Peacock immortality is embodied, resurrection and regeneration, because his body does not deсау. (Мирковић 1982: 166).

The scene with peacocks is framed with red borders. It is an integral part of the circular course of narration, of the new narrative style of the Constantine's era. From the northern (the earthly

16 With well-known motifs of the water of life-aqua vitae and the tree of life-arbor vitae, the artist illustrates the old Christian doctrine about eternal peace in paradise-pax aeterna in paradiso, i.e. Christian peace in paradise-pax christiana in paradiso. (Korać 2007: 43-48). rider), over the eastern (where the peacocks are), then south wall (the heavenly rider), the story ends with the depiction of Christ's monogram, on the western wall. Positions of the figures which dynamically aspire toward right, confirm the artist's idea of some kind of "kinetic" composition. In the representation of peacocks over the kantharos, the most common element of the composition is the symmetry, however here this was stressed with the turned head of the right peacock, toward the south wall, i.e. toward the depiction of the Heavenly rider, who is looking toward the focus of the composition, apropos Christ's monogram. The artist correctly accomplishes human and animal forms, and those forms he shapes with contours and lines, which describe the details of the faces, the drapery, and animals' bodies. Unlike precise lines of the monogram, peacocks are rendered with much more freedom in brush stroke and the manner of painting. Impressionistic poetics, which influ- 


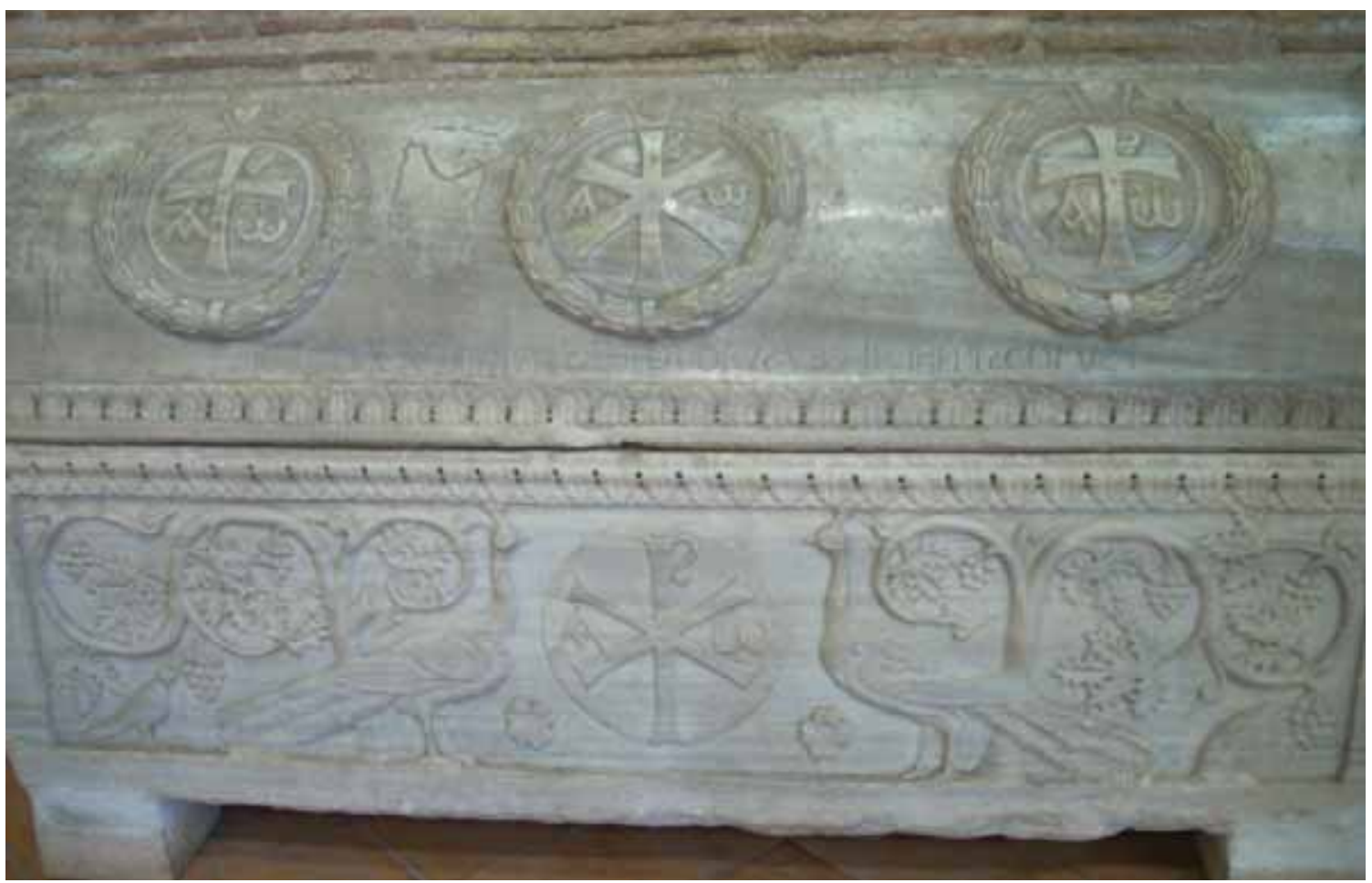

Fig. 12 - Bishop Theodore's sarcophagus in the right nave of the church of San Apollinare in Classe, Ravenna, peacocks with Christ's monogram.

enced the artist, is best seen on the figures of peacocks and vines. Colors which dominate are red and blue, on the northern and southern walls with representations of earthly and heavenly horsemen. The eastern wall with a scene of paradise makes colorful and then symbolic balance between red, color of earth and material, and apothropaic blue, color of the sky and higher spheres.

Peacocks with the same symbolic meaning are found in the analogous funerary art from nearby provinces, in Moesia Inferior, ${ }^{17}$ then in Pannonia Superior,$^{18}$ Dacia Mediterranea,${ }^{19}$ in Asia Minor,${ }^{20}$

17 In Silistra peacocks over the kantharos are located in the lunette of the western wall, above the representation of a married couple. (Димитров and Чичикова 1986: 33-35, 53, figs. 41, 53, 57; Danov and Ivanov 1980: 105-121).

18 In Pécs on the vault of the tomb on the eastern and western side kantharoi are located, flanked by peacocks. (Fulep, Bachman and Pinter 1988: 22-27).

19 In the tomb marked with number 1 from the Sofia necropolis in the lunette of the south wall, peacocks are found with the cross. (Миятев 1925: 5-14).

20 In Iznik on the east wall of the peacocks are displayed around the kantharos in the west were placed frontally. (Firatly 1974: 919-929). as well as in Macedonia. ${ }^{21}$ Peacocks are the most common decoration of Roman catacombs, where their own symbolism is subordinated to universal cosmic drama. Here, besides central moving figurative motif, there are planets, elements, personifications of the seasons, combined with traditional allusions to the earth (vine, animals) and heaven, whose symbolic meaning is expressed with a bird, usually peacock. ${ }^{22}$ This cosmological meaning of

21 In tombs of Thessalonica. On the longitudinal side of the tomb 2 (Tomb of Eustorgios), among fruits and flowers, on the pedestal, there is a glass vase from which water emerges, with two peacocks on the sides. (Pelekanidis 1963: 8-12). In the lunette of the eastern wall of the tomb 3 (Tomb of the Good Shepherd), there are poorly preserved representations of two confronted peacocks, it is not certain what was exactly located between them. (Pelekanidis 1963: 12-18). In the tomb marked with number 5 on the narrower wall opposite of the entrance, in the upper part, two peacocks are represented, among them there is the vase full of fruits. (Đurić 1985b: 85). In the middle of the western lunette of the tomb marked with number 7 , there are peacocks, which flanked a large handled kantharos. (Đurić 1985b: 88-89).

22 With the pagan meaning, we find peacock in a small niche under the stairs among tombs of the necropolis on the Via Ostiense. (Della Portella 2000: 82-92). On the 


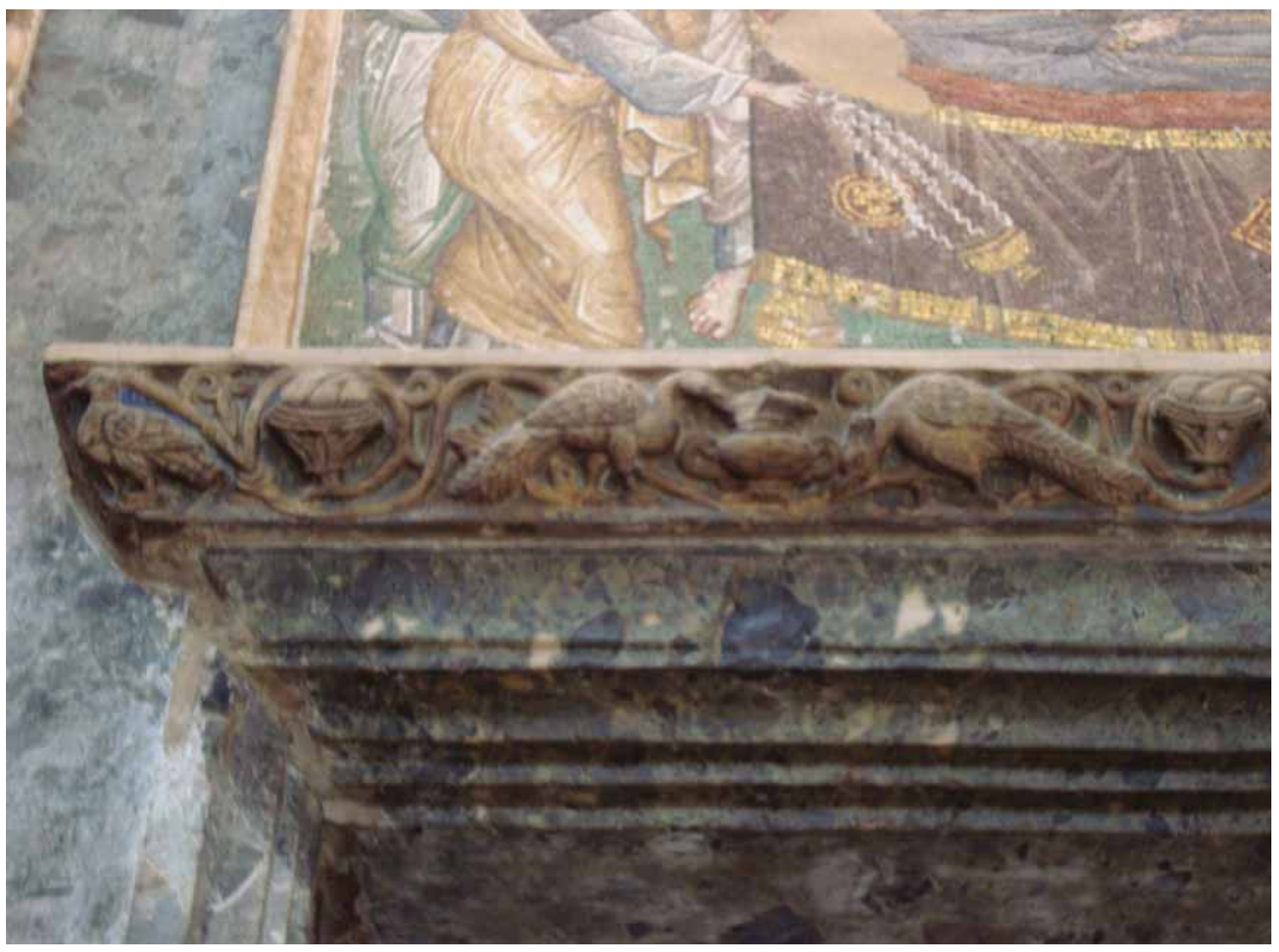

Fig. 13 - Transom in the Church of Holy Savior in Chora, Constantinople.

the Christian catacombs was transferred to the late antique and early Christian mosaic floors (usually of baptisteries, basilicas or churches in general). On the territory of today's Serbia, peacocks depicted on mosaics are found only in two places.

In the western part of the nave of the triconh building outside the walls of Caričin Grad (Iustiniana Prima), remains of a mosaic composition of the central framed panel are located, which contains a symmetrical image of two peacocks and a kantharos with vine between them. (ЦветковићТомашевић 1978: 17, fig. 9; Мано-Зиси 1955: 127-168, fig. 52; Кондић and Поповић 1977:

ceiling of Priscilla's catacomb cubiculum, a pair of quails (birds of the earth) alternates with a pair of peacocks (birds of the heaven) in basic parts, which rotate around the trigger force of the Good Shepherd. In private hypogeum at Via Dino Compagni, peacocks are painted over the kantharos with garlands, stylistically belonging to the manner of the Hellenistic painting. (Fiocchi Nicolai, Bisconti and Mazzoleni 2002: 95-98, fig. 107, 108, 115).
135-139, fig. 99). Birds, fruits and curative herbs are situated on other panels. From the mosaic of peacocks only their legs and tails have been preserved. This mosaic is dated in the mid of the sixth century. "The mosaic with peacock", is mentioned in reports as one of the four floor mosaics found in Ulpiana (Iustiniana Secunda). It is from a later period than the previous three, early Byzantine and it was found in the southern part of the town. According to the published photograph of a peacock in a square section, Gordana CvetkovićTomašević assumed that this is just one from a square mesh, which could have covered the rectangular area of the composition. (ЦветковићТомашевић 1978: 17-18, fig. 12; Čerškov 1969: fig. 8). In the neighboring countries, we find similar examples of church decorations, baptisteries or palaces floors from early Byzantine period $\left(5^{\text {th }}\right.$ to $6^{\text {th }}$ century), where in the cosmic symbolism 


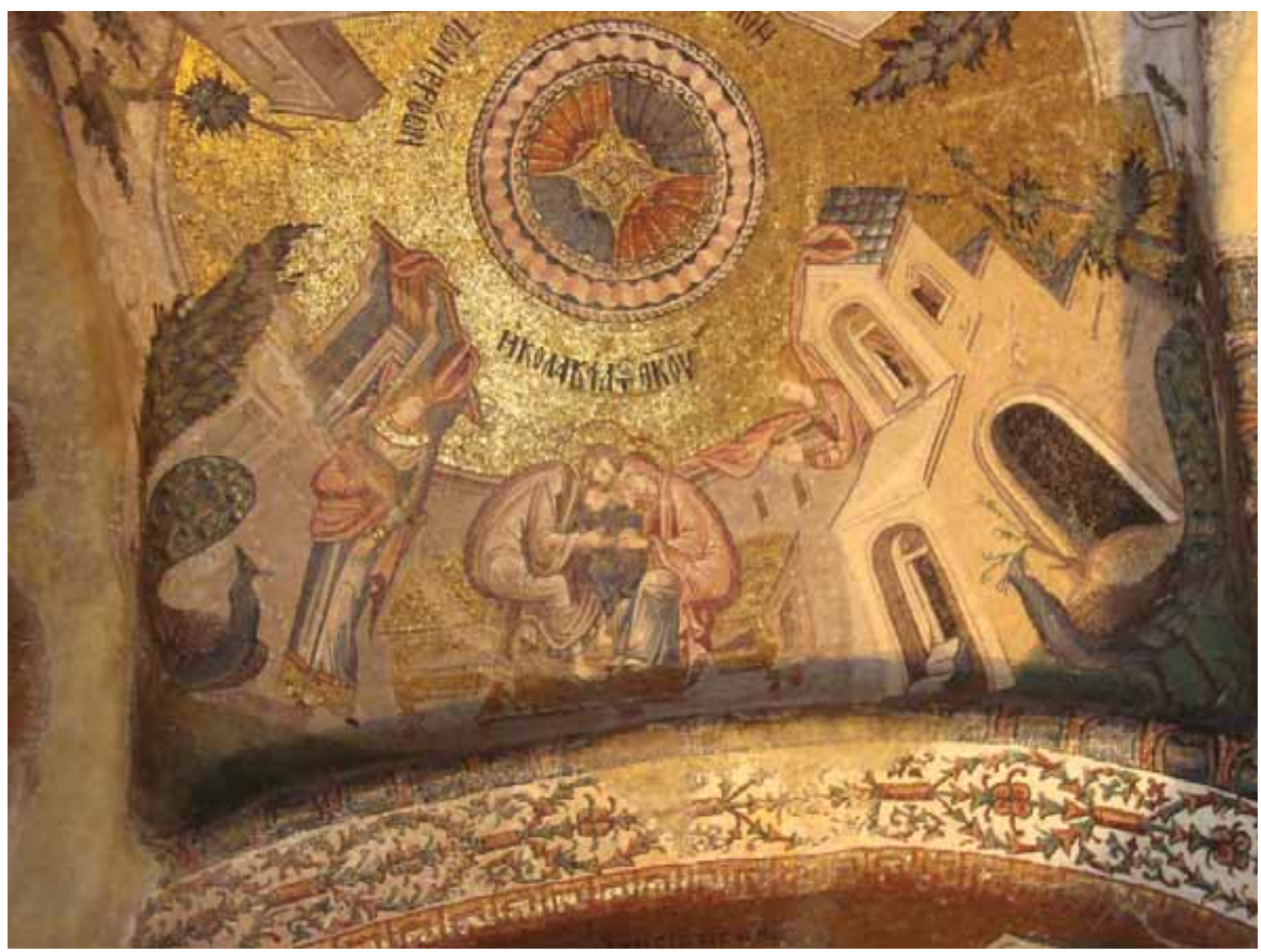

Fig. 14 - Church of Holy Savior in Chora (narthex), Constantinople, peacocks in the scene

"Caressing of Mary".

birds of earth and birds of the haven are the main zoomorphic motifs, so peacocks are frequently appearing independently as heraldic symbols arranged around kantharos or in combination with other animals, whose symbolism continues to allude to baptism, the resurrection and paradise. ${ }^{23}$

Peacocks frequently appear here in the

23 One of the best preserved mosaics with peacocks is located in the baptistery of Episcopal basilica in Butrint. On the external side of the building, remains of a Roman mausoleum are preserved. This reference to the Roman funerary architecture was purposeful, because the symbolism of baptism was closely linked with death and resurrection. (Ceka 1999: 46-48, pl. 2). Likewise peacocks over kantharos alone or with other birds and animals we find in Roman provinces Macedonia Prima-Greece and FYROMRepublic of Macedonia (Philippi, Amphipolis and Heraclea Lyncestis), Macedonia Secunda-FYROM- Republic of Macedonia (Stobi) and New Epirus-FYROM- Republis of Macedonia (Ohrid ). (Цветковић-Томашевић 1978: 19-21, 30-32, 33-34, 35, 35-37, 42, 48, 50, figs. 16, 18, 42, $46,51,52,60,74,78)$. themes of Christian cosmos, ${ }^{24}$ baptism and resurrection with the sacramental blood of Christ and the wine of the Eucharist, symbolized with kantharoi with wine or grape vines and two peacocks, birds which in Christianity remain associated with paradise and immortality. (Ceka 1999: 46-48). Thus, in such a strictly symbolically defined context, peacock becomes a sign, the character of a sort of pictorial language.

Early Byzantine art develops the motive and the meaning of peacock, not only in floor mosaics, but also elsewhere in the temple, as well as on stone sculptures. On the wooden door of the Basilica of Sant'Ambrogio in Milan, among peacocks, birds of immortality stands corona victoriae, so these animals from here, and throughout whole

24 More about symbolic representations, interpretations and meanings of cosmos in: (Цветковић-Томашевић 1978: 87-101). 
Ravenna art in stucco decoration, decoration of the sarcophagus, or presbyterium of the imperial church of San Vitale, become part of the complex angelic composition of Victory. ${ }^{25}$ (Fig. 11, 12) In Byzantine art, peacock still appears in the usual iconographic repertoire, but also in many new places in his developed decorative and symbolic form. ${ }^{26}$ (Fig. 13, 14, 15) Unlike the ancient compositions where zoomorphic, vegetable and geometric motifs, along with personifications and allegories, partici-

25 On the sarcophagi usually between two palm trees, peacocks flank Christ's wreath, monogram, cross or kantharos as a symbol of living water, as birds of immortality among the trees of life they are located in Eucharistic vine or on the top of the paradisiacal hill with four rivers. With the tree of life peacocks acquire the needed symbolic of resurrection in a complex program of presbytery in the Church of San Vitale in Ravenna. (Gerke, 1973: 138, 180, 217). On the barrel vault of the vestibule of the Archbishop chapel, on a golden background of the paradisiacal heaven, among multitude of birds there are peacocks too. (Bovini 1957: Tav. 13; G. Bovini 1969, fig. on page 47). Near the stairs which are leading from the central nave of the church in San Apollinare in Classe to the raised choir, three large carved marble slabs (transenna) are placed, decorated with a cross on the bowl from which vine emerges and on which there are two peacocks standing. Marble Pluteus (VI century) decorated with a bowl and Christ monogram, towards which two peacocks approach, on the vine. (ibid. : figs. on pages 127,131$)$. Sarcophagi from $5^{\text {th }}$ century, of Bishop Theodore (peacocks with the monogram of Christ) and a sarcophagus with six niches (peacocks with kantharos) in the right nave of the church of San Apollinare in Classe. (Bustacchini 1988: 88-89, figs. 3, 4, 153).

26 The first columns decorated with "peacock's eyes" are at Theodosius' forum in Mese street in Constantinople, Holy Cities Bethlehem (peacock appeared for the first time in front of the Bethlehem grotto) and Jerusalem their paradisiacal spaces and marks of places of birth and Calvary of Christ illustrate settled with peacocks (Rotunda of St. George in Thessalonica (IV century), the Church of Holy Savior in Chora (narthex) in the scene of Caressing of Mary (XIV century)), and there are peacocks also in the stone decoration (transom in the Church of Holy Savior in Chora and pillars of the Church of Constantine Lips (X-XIII century)). (Лазарев 2004: 21-35, 156-188, figs. 2, 465; Mathews 1976: 322-345). Spatially framed in a niche of the Church of St. Polyeuctus, spread tail of a peacock as architectural decoration today ornaments the lapidarium of the Archaeological Museum in Istanbul. Secular symbolism of peacock was recorded in the bedroom decoration of the new imperial palace of Basil I, in which, in the central medallion of mosaic on the floor, a peacock with shining red plumage was depicted. (Дил 2007: 21-22).

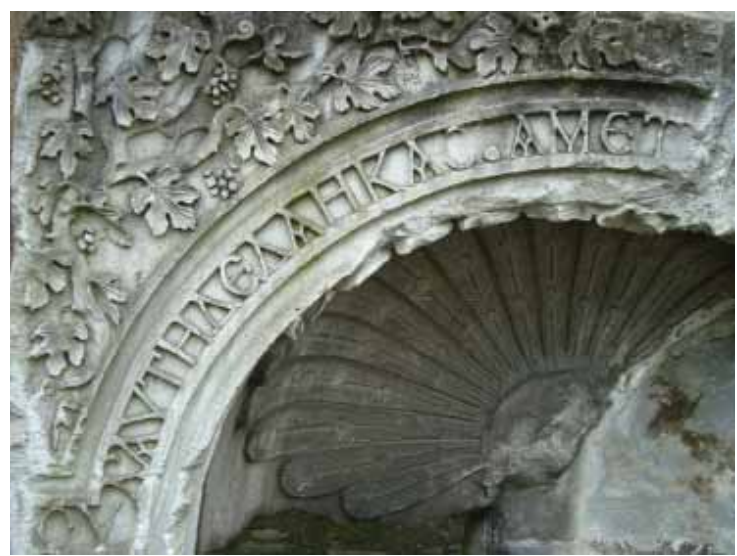

Fig. 15 - Archaeological Museum in Istanbul, niche from the Church of St. Polyeuctus, spread tail of a peacock.

pate in a large mythological or pastoral narrative, in Christianity, each animal itself carries a certain quality of its symbolic character, with which it is being included in the narration, sometimes with more or less associations. Animals, plants, certain celestial spheres, the earthly elements, due to their specific characteristics, played an important role in man's life. Thus, their sign language was created, with which they acted in art, religion, rites, and magic.

From Hera's and Juno's attributes, through the Garden of Eden in the world of the blessed, providing apotheosis to the deceased, peacock as an ancient symbol, in Christianity obtained his well-known features which will mark him up to the present day. An ancient sacred bird became a Christian bird which means holiness. Because of the belief that his flesh is eternal, falling plumes and its re-growth in the spring, in Christianity peacock became the dominant symbol of renewal and resurrection. (Biederman 2004: 291-292).

The eyes of his tail are interpreted as the "Allseeing Church". (Јовановић 2009: 526). Negative interpretations he acquired in the early Christian Physiologist, ${ }^{27}$ after which, in books about animals,

27 Collection of the symbolic and allegorical stories (letters) about animals, plants and minerals. It originated somewhere from the East, perhaps from Alexandria, between second and fourth century. It has been translated 
through the Middle Ages, peacock is mentioned as an animal which symbolizes loft, vainglorious, vanity, luxury and proud. (Ferguson 2002: 23). The long tradition of veneration of these birds in art and religion, led to a general acceptance of peacock in folk beliefs and rites. According to folk belief, it was assumed that peacock's plumage is an amulet for protection against evil eyes, because of numerous buds on the tail plumage, and eye as an amulet has long been known to some nations. (Срејовић and Цермановић-Кузмановић 1979: 97-98; Влаховић and Ацић 1953: 228-239). As an animal which protects from spells as well as an animal with beautiful colorful plumage, with which he could symbolize splendor, he incorporated the ornament of nature. People extolled him in songs, named dances by his name, compare him with the gods, so to this day the frequency and importance of this bird is reflected in Serbian personal name Paun or surname Paunović. (loc. cit.).

Translated by
Jelena Anđelković

into many languages, and had a long tradition in the Byzantine Empire. Letter about peacock the bird: Peacock is very beautiful, walks with great beauty, shimmers in his silken and extols very much. And when he sees his foot, he calls sadly and says: Oh Lord, why don't you create my foot as my body! So you too, man, take care of all the wonders which God gave you. So with mind you envy and you do not know from where it came to you. You are looking at gold and silver on you, and don't remember the poor. Take a lot of the God's talents and give them to poverty to make for your soul eternal life. If you get a wound, you ask for a doctor to cure you. Cure your mental wounds, because the medicine is church and charity for the soul. Six days the Lord gave you to work and the Holy Sunday to stand before God with fear that your sins may be forgiven. (Trifunović 1973: 17).

\section{BIBLIOGRAPHY}

\section{Biderman, H. 2004}

Paun, in: Rečnik simbola, Beograd: Stylos: 291292.

\section{Bovini, G. 1957}

Mosaici di Ravenna, Mausoleo di Galla Placidia, Battistero della Cattedrale, Capella Arcivescovile, Battistero degli Ariani, San Apollinare Nuovo, San Vitale in Classe, Milano: „Silvana“ editoriale d'arte.

\section{Bovini, G. 1969}

Ravenna an Art City, Ravenna: Edizioni A. Longo.

\section{Brem, A. E. 1982}

Paun, in: Život životinja, Zagreb: Prosveta: 309310.

\section{Bustacchini, G. 1988}

Ravenna Capital of mosaic, Ravenna: Salbaroli Publications.

\section{Cermanović, A. and Srejović, D. 1996}

Dionis, Hera, Junona, in: Leksikon religija i mitova drevne Evrope, Beograd: Savremena administracija: 107-110, 212-213, 263-265.

\section{Цветковић-Томашевић, Г. 1978}

Рановизантијски подни мозаици, Дарданија, Македонија, Нови Епир, Београд: Филозофски факултет, Институт за историју уметности.

\section{Čerškov, E. 1969}

Rimljani na Kosovu i Metohiji, Beograd: Arheološko društvo Jugoslavije.

\section{Čremošnik, I. 1984}

Mozaici i zidno slikarstvo rimskog doba u Bosni i Hercegovini, Sarajevo: „Veselin Masleša“. 


\section{Danov, H. and Ivanov, T. 1980}

The Silistra tomb, Antique tombs in Bulgaria, Sofia: Sofia Press.

\section{Della Portella, I. 2000}

Subterranean Rome, Cologne: Könemann.

Дил, Ш. 2007

Византијске слике, Београд: Просвета.

Димитров, Р. and Чичикова, М. 1986

Късноантичната гробница при Силистра, София: Бьлгарски художник.

\section{Đorđević, M. 2007}

Arheološka nalazišta rimskog perioda u Vojvodini, Archaeological Sites from the Roman Period in Vojvodina, Beograd: Republički zavod za zaštitu spomenika kulture Beograd, Institute for the Protection of Cultural Monuments of Serbia, Belgrade.

\section{Đurić, S. 1985a}

The Late Antique Painted Tomb from Beška, Зограф 16: 5-18.

\section{Đurić, S. 1985b}

Kasnoantičke i ranohrišćanske zidane grobnice u Iliriku (III-VI v), Doktorska teza, Filozofski fakultet, Univerzitet u Beogradu.

\section{Ferguson, G. 2002}

Peacock, in: Signs \& Symbols in Christian Art, London Oxford New York: Oxford University Press: 23.

Fiocchi Nicolai, V., Bisconti, F. and Mazzoleni, D. 2002

The Christian Catacombs of Rome, History, Decoration, Inscriptions, Regensburg: Schnell \& Steiner.
Firatly, N. 1974

An Early Byzantine Hypogeum Discovered at Iznik, Melanges Mansel 2, Ankara: Türk Tarih Kurumu Basımevi: 919-932.

Fulep, F., Bachman, Z. and Pinter, A. 1988 Sopianae - Pecs, Budapest: Kepzomuveszeti Kiado.

Gerbran, A. and Ševalije, Ž. 2004

Kalež, Korpa, Paun, Pehar, in: Rečnik simbola, mitovi, snovi, običaji, postupci, oblici, likovi, boje, brojevi, Novi Sad: Stylos: 345-347, 398, $679,689$.

\section{Gerke, F. 1973}

Kasna antika i rano hrišćanstvo, Novi Sad: Bratstvo Jedinstvo.

\section{Јанићијевић, Г. 2009}

Портрет жене из Viminaciuma могући кључ за одгонетање иконографског садржаја античке сепукралне уметности, Иконографске студије 2 2008, Београд: Академија - Висока школа Српске православне цркве за уметност и конзервацију: 135-143.

Јовановић, 3.М. 2009

Паун, in: Кроз двери ка светлости, лексикон литургике, симболике, иконографије и градитељства превославне цркве, Стара Пазова: САВПО: 526.

Кондић, В. and Поповић, В. 1977

Царичин Град, утврђено насеље у византијском Илирику, Београд: Српска академија наука и уметности.

\section{Korać, M. 1993}

Late Roman Tomb with Frescoes from Viminacium, Старинар (н.c) XLII, (1991): 107122. 


\section{Korać, M. 2007}

Slikarstvo Viminacijuma, Beograd: Centar za nove tehnologije - Viminacium.

\section{Лазарев 2004}

Лазарев В., Историја византијског сликарства, Београд: Александрија.

\section{Lother 1929}

Lother H., Der Pfau in der altchistliche Kunst, Leipzig: Studien über christliche Denkmäler.

\section{Мано-Зиси, Ђ. 1955}

Ископавање на Царичином Граду 1949-1952 године, Старинар (н.с.) III-IV (1952-53): 127168.

\section{Марић Р. 2003}

Антички култови у нашој земљи, Београд: Чигоја штампа.

\section{Маријански - Манојловић, М. 1987}

Римска некропола код Бешке у Срему, Нови Сад: Војвођански музеј.

\section{Mathews, T. F. 1976}

The Byzantine Churches of Istanbul, A Photographic Survey, University park, London, The Pennsylvania State University Press 1976.

\section{RIC II}

Mattingly H., Sydenham E.A., The Roman Imperial Coinage, London 1962.

\section{RIC III}

Mattingly H., Sydenham E.A., The Roman Imperial Coinage, London 1930.

\section{RIC V/1}

Mattingly H., Sydenham E.A., Webb P.H., The Roman Imperial Coinage, London 1972.

\section{Мирковић, Л. 1954-55}

Старохришћанска гробница у Нишу, Старинар (н.c.) V-VI: 53-71.

\section{Мирковић, Л. 1982}

Православна литургика I, Београд: Свети архијерејски синод Српске православне цркве.

Миятев, К. 1925

Декоративната живопис на Софиския некропол, София: Придворна печатница.

\section{Oakeshott, W. 1977}

Мозаици Рима, Од трећег до четрнаестог века, Београд: Југославија.

\section{Овчаров, Д. and Ваклинова, М. 1978}

Ранновизантискит паметници от България IVVII век, София: Септември.

\section{Pelekanidis, S. 1963}

Gli affreschi paleocristiani ed I piu antichi mosaici parietali di Salonicco, Ravenna: Universita Di Bologna.

\section{Rakocija, M. 2009}

Painting in the cript with an anchor in Niš, Ниш и Византија, зборник радова VII, M. Rakocija, (ed.), Ниш: Нишки културни центар: 87-105.

\section{Спасић-Ђурић, Д. 2002}

Виминацијум главни град римске провинције Горње Мезије, Viminacium the capital of the Roman province of Upper Moesia, Пожаревац: Народни музеј.

\section{Срејовић, Д. and Цермановић-Кузмановић}

\section{A. 1979}

Горгона, Јунона, in: Речник грчке и римске митологије, Београд: Српска књижевна задруга: 97-98, 182-183. 
Стричевић, Ђ. 1956 - 1957

Брестовик - Римска гробница, Страинар (н.с.) VII - VIII: 411-413.

\section{Трифуновић, Ђ. (trans.) 1973}

Физиолог, слово о ходећим и летећим створењима, Пожаревац: Књижевни часопис "Браничево“"

Валтровић, М. 1906

Римска гробница у селу Брестовику, Старинар (н.р.) I: 128-138.

Влаховић, П. Ш. and Ацић, П. 1953

Паун у народној религији, умотворинама и уметности, Гласник Етнографског музеја у Београду XVI: 228-239.

Volbach, W. F. 1961

Early Christian Art, London: Thames and Hudson.

\section{REZIME}

PAUN KAO ZNAK U KASNOANTIČKOJ I RANOHRIŠĆANSKOJ UMETNOSTI

KLJUČNE REČI: PAUN, ZNAK, UMETNOST, SLIKARSTVO, KASNA ANTIKA, RANO HRIŠĆANSTVO, GROBOVI, FRESKE, MOZAIK.

Zbog osobitih prirodnih karakteristika, naročito okaca na repnom perju, paun je vrlo rano dobio izuzetno mesto u verovanjima, običajima, religiji i umetnosti mnogih naroda. Poreklom sa Cejlona i Indije, preko Male Azije dospeo je u Evropu, u kojoj je postao sveta ptica grčke boginje Here i rimske Junone. Preko ove boginje povezan je sa rimskim caricama, pa je čest motiv na reversima njihovog novca. Zbog svojih simboličkih funkcija, paun je nezaobilazni deo scenskog repertoara raja u funerarnom slikarstvu. U kasnoantičkim i ranohrišćanskim fresko os- likanim grobnicama, sa prostora današnje Srbije i okolnih zemalja, u paganskom kontekstu paun se preko vinove loze, grožđa i vina najčešće povezuje sa Dionisom, ali je takođe atribut najvećeg ženskog božanstva Rimljana - Junone. U paganskom kontekstu paunove nalazimo predstavljene u šest grobnica Viminacijuma (G5464, G4734, G3130, G5313, G2624 i G160 ) i u grobnici u Beškoj. Prikazani samostalno ili u paru, kao drevni simboli pobede nad smrću i besmrtnosti, od paganske apoteoze paunovi u hrišćanstvu postaju deo hrišćanskog raja. U hrišćanskom funerarnom slikarstvu, paunove nalazimo nad kantarosom ispunjenim vodom i sa drvetom života u viminacijumskoj "Grobnici sa Hristovim monogramom" G5517. Čest je motiv na ranohrišćanskim podnim mozaicima krstionica ili crkava. Na ovakvim mestima simbolički aludira na krštenje, vaskrsenje i raj, najčešće u temama hrišćanskog kosmosa. Sa ovim značenjem paunove nalazimo na dva podna mozaika sa teritorije današnje Srbije: u trikonhosu u Caričinom Gradu (Iustiniana Prima) i u Ulpijani (Iustiniana Secunda). Kao kontinuirani motiv u paganskoj i hrišćanskoj umetnosti, u simbolički strogo definisanom kontekstu, ova ptica vremenom je dobila osobinu znaka, karaktera svojevrsnog slikovnog pisma. Preko ravenske i carigradske srednjovekovne umetnosti, paun je svoje značenje i istaknuto mesto u vizuelnoj kulturi istoka i zapada zadržao sve do danas. Duga tradicija poštovanja ove ptice u umetnosti i religiji, dovela je do opšteg narodnog prihvatanja pauna u verovanjima i običajima, pa se smatralo da je njegovo perje amajlija za zaštitu od zlih pogleda. Narod je pauna poredio sa bogovima. Deci, pesmama i igrama davana su imena po ovoj ptici. 